\title{
Comparison of thermophilic and mesophilic anaerobic treatments for potato processing wastewater using a contact reactor
}

\author{
İnce $E .^{1,{ }^{*}}$, İnce M. ${ }^{2}$ and Önkal Engin G. ${ }^{2}$ \\ ${ }^{1}$ Department of Environmental Engineering, Gebze Technical University, Cayirova Campus, 41400, Gebze, Kocaeli, Turkey \\ 2Department of Environmental Engineering, Yildiz Technical University, Davutpasa Campus, 34220, Esenler, İstanbul, Turkey \\ Received: 09/09/2016, Accepted: 10/01/2017, Available online: 05/10/2017 \\ *to whom all correspondence should be addressed: e.senturk@gtu.edu.tr
}

\begin{abstract}
In this study, different organic loading rates (OLRs) ranging from 1.1 to $5.0 \mathrm{~kg} \mathrm{COD} / \mathrm{m}^{3}$. day were used to assess the performance of an anaerobic reactor at the optimum mesophilic $\left(35^{\circ} \mathrm{C}\right)$ and thermophilic $\left(55^{\circ} \mathrm{C}\right)$ temperatures. The methane gas production rate of the thermophilic treatment was higher than that of the mesophilic treatment. The efficiency of chemical oxygen demand (COD) removal was observed to range from 89.12 to $93.20 \%$ following the thermophilic anaerobic treatment and from 76.36 to $92.62 \%$ following the mesophilic treatment. The average VFA (volatile fatty acid)/alkalinity ratio of the effluent was 0.3 under both thermophilic and mesophilic conditions for all the OLR applications. The $\mathrm{HPr} / \mathrm{HAc}$ (propionic acid/acetic acid) ratio was calculated as 0.16 and 1.3 for the mesophilic and thermophilic treatments, respectively. For the mesophilic treatment, the average methane gas production was found to be $0.394 \mathrm{~m}^{3} \mathrm{CH}_{4} / \mathrm{kg}$ CODremoved while it was $0.42 \mathrm{~m}^{3} \mathrm{CH}_{4} / \mathrm{kg}$ $\mathrm{COD}_{\text {removed }}$ for the thermophilic experiment. However, the sludge settleability of the mesophilic treatment was better than that of the thermophilic treatment.
\end{abstract}

Keywords: mesophilic, thermophilic, anaerobic treatment, wastewater, contact reactor

\section{Introduction}

Anaerobic wastewater treatment differs from conventional aerobic treatment in that in the former, no aeration is applied. The lack of oxygen leads to controlled anaerobic conversions of organic pollutants to carbon dioxide and methane, the latter of which can be utilised as an energy source. The main advantages of anaerobic treatment include operability at very high loading rates (10 to 20 times as high as in the conventional activated sludge treatment) and less operating costs and reduced waste sludge.

Anaerobic treatment can be conducted at psychrophilic $\left(<25^{\circ} \mathrm{C}\right)$, mesophilic $\left(25-40^{\circ} \mathrm{C}\right)$, and thermophilic $\left(>45^{\circ} \mathrm{C}\right)$ temperatures (El-Mashad et al. 2004). However, only mesophilic and thermophilic ranges provide optimum anaerobic conditions for the production of methane. The mesophilic range is between $20^{\circ} \mathrm{C}$ and $40^{\circ} \mathrm{C}$ with the optimum temperature being $35^{\circ} \mathrm{C}$. The thermophilic temperature ranges from $50^{\circ} \mathrm{C}$ to $65^{\circ} \mathrm{C}$ with an optimum temperature of $55^{\circ} \mathrm{C}$.

The effect of temperature changes on the first stage of the digestion process (hydrolysis and acidogenesis) is not very significant. The second and third stages of decomposition can only be performed by certain specialised microorganisms (acetogenic and methanogenic bacteria) and thus, these are much more sensitive towards changes in temperature. However, an important characteristic of anaerobic bacteria is the decrease of the decomposition rate below $15^{\circ} \mathrm{C}$. Thus, it is possible to maintain the activity of anaerobic sludge for longer periods. This is especially useful in the anaerobic treatment of wastewater in seasonal industries such as sugar mills.

As in all biochemical reactions, the anaerobic degradation rate of organics increases with temperature. However, the effect of temperature is often less than predicted by the van't Hoff equation, which establishes that chemical reaction rates double with each $10^{\circ} \mathrm{C}$ rise in temperature (Switzenbaum \& Jewell, 1980). There are also certain disadvantages of temperature changes on anaerobic treatment, such as resulting in poor sludge settling that brings about high-effluent suspended solids, effluent turbidity and biomass washout (Ahn \& Forster, 2002).

Food processing wastewaters, such as wastes from coffee processing, palm oil mill, cannery, distillery and ice-cream are often discharged at or above ambient temperatures. Treating these effluents under conventional mesophilic conditions requires costly pre-cooling, and also has the risk of losing biomass activity in case of a breakdown of the cooling system ( $\mathrm{Yu}$ et al. 2002). Therefore, thermophilic treatment is an attractive alternative for these wastewaters (Ahn \& Foster, 2000). Furthermore, in the thermophilic range, biodegradation occurs faster compared to mesophilic conditions; thus, the organic loading potentials of thermophilic anaerobic reactors are substantially higher (Ahn \& Foster, 2002). Despite having several significant advantages, thermophilic anaerobic treatment has certain drawbacks; e.g., it is mostly favourable for the production of propionate, for which 
further degradation is slower than in other VFAs and this type of treatment is more sensitive to environmental changes (Mclnerney, 1988; Yu et al. 2002).

Earlier studies investigating the effect of temperature on the anaerobic treatment process have mainly focused on the comparison of steady-state performance at two or more fixed operating temperatures (Kim et al. 2002; Ndegwa et al. 2008; Yilmaz et al. 2008). The effect of temperature fluctuations on anaerobic treatment efficiency has been also studied. It has been reported that a temporary decrease in temperature (between 10 and $20^{\circ} \mathrm{C}$ ) only temporarily affects the performance and stability of psychrophilic anaerobic reactors treating swine manure (Massé et al. 2003). However some of the studies conducted within the thermophilic range indicated that thermophilic process is more susceptible to environmental and operational conditions such as temperature than mesophilic process (Ahring et al. 2001; Iranpour et al. 2005). El-Mashad et al. (2004) found that the imposed daily upward temperature fluctuation affected the maximum specific methanogenic activity more severely than the daily downward temperature fluctuations in completely stirred tank reactors (CSTRs).

Despite the availability of comparisons between mesophilic and thermophilic anaerobic wastewater treatments in the literature, none of the published studies has reported experiments with an anaerobic contact reactor. Therefore, in the present study, we chose to investigate the performance of an anaerobic contact reactor under mesophilic $\left(35^{\circ} \mathrm{C}\right)$ and thermophilic $\left(55^{\circ} \mathrm{C}\right)$ conditions. This paper presents the comparison of the efficiency of the mesophilic- and thermophilic-treated anaerobic contact reactor in terms of COD removal, composition of biogas and VFAs.

\section{Material and Method}

\subsection{Wastewater Characterisation}

The wastewater used in this study was obtained from a factory producing potato chips, maize chips and other snacks.

Table 1. Wastewater characteristics (after peeling and cutting processes)

\begin{tabular}{ccc}
\hline Parameter & Unit & Range \\
\hline TCOD & $\mathrm{g} / \mathrm{L}$ & $5.25-5.75$ \\
$\mathrm{SCOD}$ & $\mathrm{g} / \mathrm{L}$ & $2.50-3.00$ \\
$\mathrm{BOD}_{5}$ & $\mathrm{~g} / \mathrm{L}$ & $4.00-5.0$ \\
Alkalinity & $\mathrm{g} \mathrm{CaCO}_{3} / \mathrm{L}$ & $2.00-2.50$ \\
$\mathrm{pH}$ & - & $7-8$ \\
Temperature & ${ }^{\circ} \mathrm{C}$ & $15-20$ \\
$\mathrm{TKN}$ & $\mathrm{g} / \mathrm{L}$ & $0.20-0.25$ \\
$\mathrm{NH}_{3}-\mathrm{N}$ & $\mathrm{g} / \mathrm{L}$ & $0.05-0.06$ \\
Sulphate & $\mathrm{g} / \mathrm{L}$ & $0.40-0.50$ \\
Total Solid & $\mathrm{g} / \mathrm{L}$ & $4.80-5.00$ \\
Total Suspended Solids & $\mathrm{g} / \mathrm{L}$ & $2.00-2.10$ \\
Total Volatile Solid & $\mathrm{g} / \mathrm{L}$ & $4.40-4.50$ \\
\hline
\end{tabular}

TCOD: Total Chemical Oxygen Demand; SCOD: Soluble Chemical Oxygen Demand; $\mathrm{BOD}_{5}$ : 5-day Biochemical Oxygen demand; TKN: Total Kjeldahl Nitrogen; $\mathrm{NH}_{3}-\mathrm{N}$ : Ammonia-Nitrogen
The wastewater produced during peeling and cutting processes was obtained as a grab sample at a volume of $100 \mathrm{~L}$ and was kept at $4^{\circ} \mathrm{C}$ for a week. After each week, a new sample of $100 \mathrm{~L}$ was collected due to the fast degradation of wastewater. This process was repeated throughout the study period. Since wastewater has a COD/N/P ratio of approximately 275/10/1 (see all characteristics in Table 1), there was no need for a supplement to adjust the nutrient level for an anaerobic treatment.

\subsection{Anaerobic Contact Reactor}

Figure 1 presents the anaerobic contact reactor used in this study. Detailed information about the configuration of this reactor is given in our previous study (Şentürk et al. 2010). The reactor was inoculated with anaerobic granular sludge obtained from an anaerobic treatment plant in a potato-processing factory. A $10 \mathrm{~L}$ heater tank was attached to the system to maintain the reactor temperature at $35 \pm 2^{\circ} \mathrm{C}$ and $55 \pm 2^{\circ} \mathrm{C}$ for mesophilic and thermophilic experiments, respectively. The $\mathrm{pH}$ of the system was monitored and controlled continuously using a $\mathrm{pH}$ meter. The water used for gas washing was acidified to $\mathrm{pH} 3$ by the addition of $\mathrm{HCl}$ and $\mathrm{NaCl}$ in order to prevent biogas dissolution. The system was equipped with a heat-insulated separation tank to prevent microorganism loss. A programmable logic controller (PLC/Siemens S7 300) was utilised to ensure that the system was working effectively. Data were obtained and visualised using WinCC SCADA (Siemens).

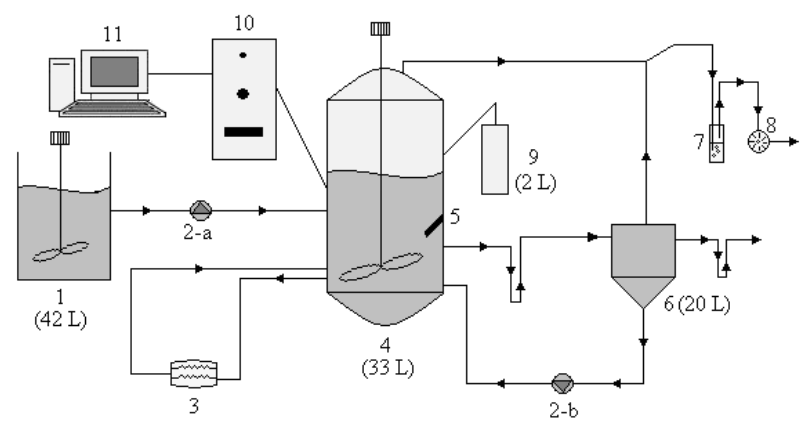

Figure 1. The schematic view and flow chart of the system used in this study; 1) Feed tank, 2 a-b) Peristaltic Pump, 3) Heater, 4) Anaerobic Contact Reactor, 5) pH meter, 6)

Separation Tank, 7) Gas washing, 8) Gas meter, 9) $\mathrm{NaOH}$ tank, 10) PLC Panel, 11) Computer

\subsection{Analytical Methods}

All the chemicals were of analytical reagent grade and distilled water was used during all experiments. The COD and $\mathrm{BOD}_{5}$ analyses were performed according to the STM $5220 \mathrm{C}$ and STM 5210 B methods, respectively (APHA, 2005) and the TKN and $\mathrm{NH}_{3}$ concentrations were determined with the STM 4500-Norg B Macro-Kjeldahl and STM 4500- $\mathrm{NH}_{3} \mathrm{C}$ methods, respectively (APHA, 2005). The STM 4500- $\mathrm{SO}_{4}{ }^{2-}$ method was utilised for sulphate analyses. The alkalinity and total volatile fatty acid concentrations were measured by the STM 2320 B and 
STM 5560 C methods, respectively (APHA, 2005). In addition, each volatile fatty acid concentration was further analysed by a gas chromatograph (Agilent) equipped with an FID detector and a Zebran ZB-Wax capillary column, $30 \mathrm{~m} \times 250 \mu \mathrm{m} \times 0.50 \mu \mathrm{m}$. Helium was used as the carrier gas. The temperature of the oven was initially set at $100^{\circ} \mathrm{C}$ for $1 \mathrm{~min}$ and then, it was gradually increased to $120^{\circ} \mathrm{C}$ by $20^{\circ} \mathrm{C} / \mathrm{min}$ followed by an increase of $6.13^{\circ} \mathrm{C} / \mathrm{min}$ up to $205^{\circ} \mathrm{C}$. The total duration of this process was 15.87 minutes. The temperature of the detector was $240^{\circ} \mathrm{C}$. The samples taken from the reactor were centrifuged at $10000 \mathrm{rpm}$ for 15 minutes at room temperature before being analysed by gas chromatography (GC). The total solids and total volatile solids concentrations were determined (STM $2540 \mathrm{~B}$ and STM 2540 C methods, respectively) (APHA, 2005).

The biogas generated was cumulatively measured using a wet gas meter (Ritter, Drum type, TG 05 Model, flow rate of 1-60 L/h). The content of the biogas $\left(\mathrm{CH}_{4}, \mathrm{CO}_{2}, \mathrm{H}_{2}\right)$ was analysed by GC (Agilent) using an HP Plot $\mathrm{Q}+$ Molecular Sieve column, $60 \mathrm{~m} \times 530 \mu \mathrm{m} \times 400 \mu \mathrm{m}$. Argon was used as the carrier gas with a gas flow of $4 \mathrm{~mL} / \mathrm{min}$. The oven temperature was initially set at $50^{\circ} \mathrm{C}$ for $5 \mathrm{~min}$ followed by a gradual increase of $5^{\circ} \mathrm{C} / \mathrm{min}$ up to $80^{\circ} \mathrm{C}$, at which it was maintained for 3 minutes. Then, the temperature was increased by $10^{\circ} \mathrm{C} / \mathrm{min}$ to $100^{\circ} \mathrm{C}$. This process took 16 minutes. The temperature of TCD was $200^{\circ} \mathrm{C}$. Significant differences were determined between the two temperatures (mesophilic and thermophilic) and different OLRs using a two-factor ANOVA.

\subsection{Experimental design}

To investigate the effect of temperature on the anaerobic contact reactor, the reactor was operated at two different temperatures, $35^{\circ} \mathrm{C}$ and $55^{\circ} \mathrm{C}$. At both temperatures, the performance of the reactor was assessed at different organic loading rates (OLRs) ranging from 1.1 to $5.0 \mathrm{~kg}$ $\mathrm{COD} / \mathrm{m}^{3}$. The hydraulic retention time (HRT) values at the corresponding OLRs were calculated from the quotient of the effective reactor volume to wastewater flow rate (Table 2). During the study, each parameter (COD, intermediate of VFAs, composition of biogas) were analysed at steady-state for each OLR.

Table 2. HRT values at corresponding OLRs

\begin{tabular}{cc}
\hline OLRs $\left(\mathbf{k g}\right.$ COD $/ \mathbf{m}^{\mathbf{3} \cdot \text { day) }}$ & HRT (day) \\
\hline 1.1 & 5.11 \\
1.5 & 3.71 \\
2.5 & 2.13 \\
3.35 & 1.64 \\
4.5 & 1.15 \\
5 & 1.06 \\
\hline
\end{tabular}

\section{Results and discussion}

\subsection{COD removal efficiency}

It is known that anaerobic reactors demonstrate better process stability under mesophilic conditions compared to thermophilic conditions (Yu et al. 2002; Poh and Chong, 2009). However, in this study, the system quickly adapted to the increase in OLRs at both temperatures $\left(35 \pm 2^{\circ} \mathrm{C}\right.$ and
$55 \pm 2^{\circ} \mathrm{C}$ ) without demonstrating any reduced efficiency. This can be mainly attributed to a CSTR being used (Meynel, 1976; Şentürk et al. 2010) and wastewater being composed of easily biodegradable pollutants such as carbohydrates and proteins (Hadjivassillis et al. 1997; Şentürk et al. 2010). The efficiency of the reactor in terms of COD removal ranged from 89.12 to $93.20 \%$ following thermophilic treatment and from 76.36 to $92.62 \%$ under mesophilic conditions (Figure 2).

The COD removal efficiency was decreased with the increased OLRs due to the decrease in HRT. As shown in Figure 2, the COD removal efficiency of the reactor was lower under mesophilic conditions since the biodegradation rate was insufficient for the corresponding HRT. These results are consistent with those reported by several researchers including Borja et al. (1995), Ahn and Forster (2000), Ahn and Forster (2002) and Yilmaz et al. (2008). At lower loading rates, there was only a slight difference between the two temperatures in term of the removal efficiency; however, this difference became greater with the increasing OLRs. When OLRs were increased to $8 \mathrm{~kg} \mathrm{COD} / \mathrm{m}^{3}$.day under thermophilic conditions, the COD removal efficiency was calculated to be approximately $84 \%$. This indicates that thermophilic anaerobic treatment can be used for higher OLRs, which supports the results reported by Ahn and Forster (2000).

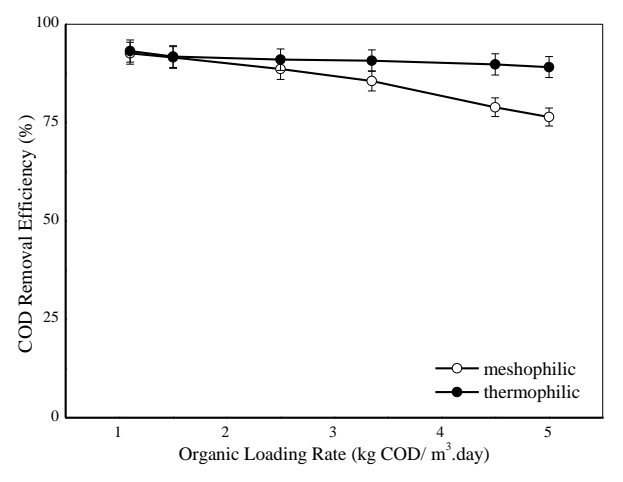

Figure 2. COD removal efficiency of the anaerobic reactor at mesophilic and

thermophilic temperatures and different OLRs.

\subsection{Intermediate products, $\mathrm{pH}$ and alkalinity}

At the beginning of an anaerobic treatment, as a result of the hydrolysis and acidification process, VFAs are produced by microorganisms (Valentini et al., 1997). At this stage, VFA production rate mainly depends on the characteristics of wastewater, environmental conditions such as temperature and $\mathrm{pH}$, reactor type and operating parameters such as HRT (Jayaseelan \& Matsuo, 1995).

As shown in Figure 3, although an increase in the VFA was observed at the initial days of organic loading, $\mathrm{pH}$ was not observed to change at mesophilic and thermophilic temperatures. The main reason for this was the high alkalinity of the potato-processing wastewater creating a buffer effect. In this study, the maximum VFA/alkalinity 
ratios for thermophilic and mesophilic conditions were found to be 0.3 and 0.5 , respectively. Both values being well below the limit value of 0.8 resulted in an inhibitory effect (Water Pollution Control Federation, 1987). Therefore, there was no need to add any chemicals such as $\mathrm{NaOH}$ and $\mathrm{NaHCO}_{3}$ to the system to adjust the $\mathrm{pH}$. In addition, alkalinity was formed in the reactor by the reaction of ammonia with carbon dioxide and water to form ammonium bicarbonate (Zhao \& Viraraghavan, 2004; Şentürk et al., 2010). One of the major criticisms about the use of thermophilic digestion is that the final effluents contain higher concentrations of VFAs compared to mesophilic digesters (Hill et al., 1985).

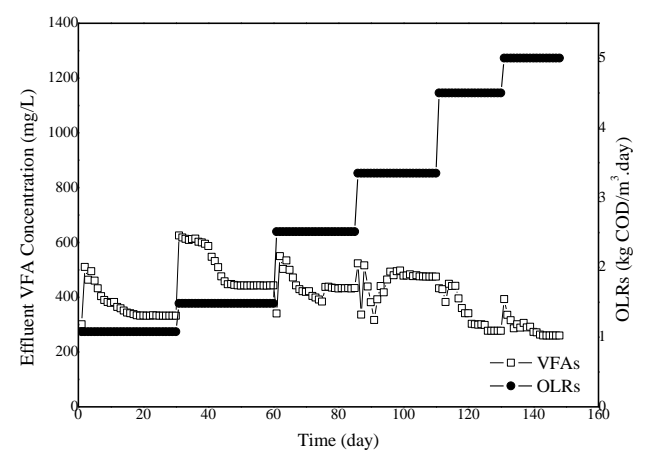

(a)

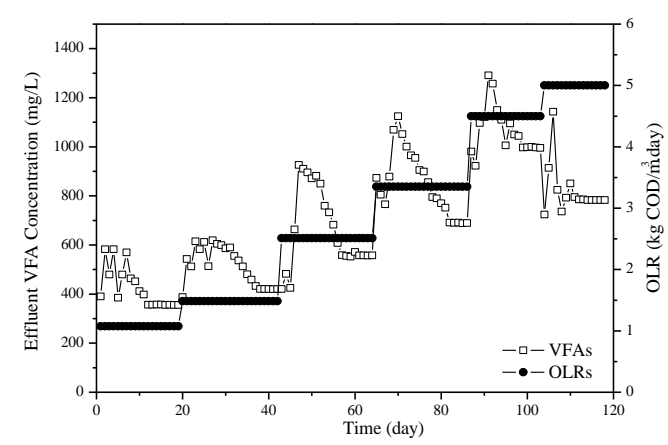

(b)

Figure 3. Effluent VFA concentrations at different OLRs (a) thermophilic, (b) mesophilic

Similarly, Harris and Dague (1993) reported that thermophilic filters produced an effluent with VFA concentrations greater than in the effluent from a mesophilic filter. Contrary to these reports, in the present study, the effluent VFA concentration of the mesophilic treatment was found to be higher than that of the thermophilic treatment, which resulted in a higher biodegradation rate under the latter conditions.

Determination of the composition of VFAs is great sinificant in anaerobic wastewater treatment, since it gives information about the metabolic pathway of the process. HAc is the most important intermediate in the production of methane. Transformation of $\mathrm{HAc}$ and $\mathrm{n}-\mathrm{HBu}$ to methane is faster than conversation of $\mathrm{HPr}, \mathrm{n}-\mathrm{HVa}$, and $\mathrm{i}-\mathrm{HVa}$ to methane. When the system reached to steadystate at each OLR, the concentrations of VFA species are given Table 3. The degradation of straight chain (normal form) VFAs is faster than their branched (iso formed) forms. In thermophilic condition, the biological degradation of HPr increased linearly with the increasing OLR up to $2.5 \mathrm{~kg} \mathrm{COD} / \mathrm{m}^{3}$.day, after this loading, it decreased owing to inadequate HRT. HAc having 2 carbons is directly converted to $\mathrm{CH}_{4}$ and $\mathrm{CO}_{2}$ by methane bacteria. But, the VFAs having more carbons than 4 cannot be converted directly by methane archaea. That's why, VFAs with high moleculer weight are transformed to HAc prior to $\mathrm{CH}_{4}$. Regarding the concentration of VFA species under mesophilic condition, HAc was higher than the others, making it the final VFA product prior to the production of methane (Ahn \& Forster, 2000; Yilmaz et al. 2008). In contrast, under thermophilic condition, HAc lesser than the other VFA species, probably due to accelerate in performance of methane archaea according to Arhenius equation. The HPr/HAc ratio was calculated to be $0.06-0.25$ and 1.13 - 1.25 for mesophilic and thermophilic treatments, respectively. As known, if this ratio reaches 1.4, the system would fail (Buyukkamaci \& Filibeli, 2004).

\subsection{Gas production and composition}

The results clearly indicate that the process was efficient in terms of biogas production and yield at all loading rates for both mesophilic and thermophilic conditions. Figure 4 presents the daily produced biogas volumes. Although biogas production increased with the increasing loading rates (Dinsdale et al. 1997; Ahn and Forster, 2000), methane had an inverse proportion to OLRs due to low HRT (Yu et al. 2002) with the methane percentages ranging from 80-89 and 79-89 for mesophilic and thermophilic temperatures, respectively.

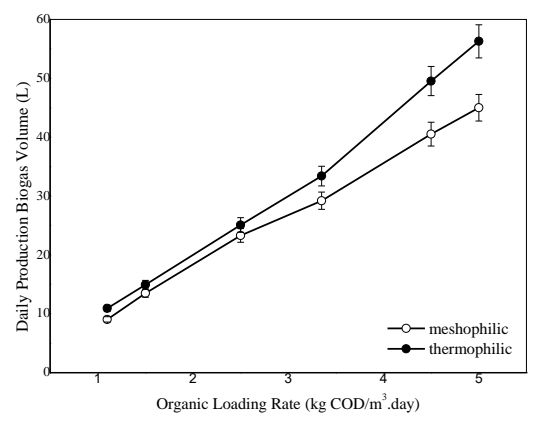

Figure 4. Daily biogas production under mesophilic and thermophilic conditions at different OLRs.

As illustrated in Figure 4, there was a linear correlation between biogas production and OLRs. It should be noted that with the increase in OLRs, the methane content of biogas slightly decreased in consistency with the available theoretical information (Metcalf \& Eddy, 2003). The average methane production was found to be $0.394 \mathrm{~m}^{3}$ 
$\mathrm{CH}_{4} / \mathrm{kg} \mathrm{COD}$ removed following the mesophilic treatment and $0.42 \mathrm{~m}^{3} \mathrm{CH}_{4} / \mathrm{kg} \mathrm{COD}_{\text {removed }}$ following the thermophilic treatment. These results show that in terms of methane production, thermophilic anaerobic treatment was better than mesophilic anaerobic treatment (Borja et al. 1995; Ahn \& Forster, 2000; Ahn \& Forster, 2002; Yu et al. 2008; Yilmaz et al. 2008). 
Table 3. VFAs composition at different OLRs for thermophilic and mesophilic.

\begin{tabular}{|c|c|c|c|c|c|c|c|c|c|c|c|c|c|c|c|c|}
\hline \multirow{2}{*}{$\begin{array}{c}\text { Organic } \\
\text { Loading Rate } \\
(\mathrm{kg} \\
\left.\mathrm{COD} / \mathrm{m}^{3} \cdot \text { day }\right)\end{array}$} & \multicolumn{8}{|c|}{ Thermophilic $\left(55^{\circ} \mathrm{C}\right)$} & \multicolumn{8}{|c|}{ Mesophilic $\left(35^{\circ} \mathrm{C}\right)$} \\
\hline & HAC & $\mathrm{HPr}$ & $\mathrm{n}-\mathrm{HBu}$ & $\mathrm{i}-\mathrm{HBu}$ & $\mathrm{n}-\mathrm{HVa}$ & $\mathrm{i}-\mathrm{HVa}$ & $\mathrm{n}-\mathrm{HCa}$ & $\mathrm{i}-\mathrm{HCa}$ & HAC & $\mathrm{HPr}$ & $\mathrm{n}-\mathrm{HBu}$ & $\mathrm{i}-\mathrm{HBu}$ & $\mathrm{n}-\mathrm{HVa}$ & $\mathrm{i}-\mathrm{HVa}$ & $\mathrm{n}-\mathrm{HCa}$ & $\mathrm{i}-\mathrm{HC}$ \\
\hline 1.1 & 27.38 & 31.02 & 10.00 & 41.73 & 27.38 & 0.00 & 52.23 & 54.35 & 185.45 & 20.42 & 34.57 & 34.50 & 20.42 & 10.46 & 14.48 & 20.23 \\
\hline 1.5 & 31.25 & 39.40 & 39.90 & 59.10 & 31.25 & 48.8 & 50.5 & 52.50 & 284.05 & 17.04 & 15.05 & 14.20 & 21.54 & 12.45 & 17.89 & 10.02 \\
\hline 2.5 & 40.61 & 49.88 & 55.01 & 55.88 & 40.61 & 55.13 & 51.17 & 55.67 & 313.07 & 26.92 & 17.94 & 13.96 & 24.61 & 23.98 & 48.59 & 29.25 \\
\hline 3.35 & 33.42 & 41.74 & 41.15 & 55.89 & 33.42 & 50.03 & 53.92 & 57.29 & 361.79 & 67.34 & 49.80 & 47.80 & 49.92 & 49.02 & 53.44 & 30.53 \\
\hline 4.5 & 24.26 & 30.38 & 33.21 & 38.39 & 24.26 & 36.75 & 32.37 & 33.46 & 398.25 & 96.94 & 89.16 & 87.60 & 78.45 & 77.62 & 89.44 & 46.35 \\
\hline 5 & 17.47 & 20.64 & 39.84 & 38.22 & 21.47 & 31.75 & 30.47 & 26.25 & 328.52 & 69.90 & 59.28 & 55.68 & 54.13 & 50.47 & 77.83 & 21.13 \\
\hline
\end{tabular}

HAc: Asetic acid; HPr: Propiyonic acid; HBu: Butiric acid; HVa: Valeric acid; HCa: Caproic acid; i-: iso; n-: normal 
Table 4 presents the content of the produced biogas. Hydrogen was only determined following the thermophilic treatment at the first OLR. At all other OLRs, fermentative hydrogen-producing bacteria may have been washed out from the reactor due to the decrease in HRT with the increasing OLR (Guo et al. 2008). It has previously been reported that hydrogen is produced via ß-oxidation during the conversion of long-chain fatty acids (Abdel-Halim, 2005).

Table 4. Content of biogas at different OLRs at mesophilic and thermophilic temperatures

\begin{tabular}{|c|c|c|c|c|}
\hline \multirow{2}{*}{$\begin{array}{c}\text { OLR (kg } \\
\text { COD } / \mathrm{m}^{3} . \text { day) }\end{array}$} & \multicolumn{2}{|c|}{$\begin{array}{c}\text { Mesophilic } \\
\left(35^{\circ} \mathrm{C}\right)\end{array}$} & \multicolumn{2}{|c|}{$\begin{array}{l}\text { Thermophilic } \\
\left(55^{\circ} \mathrm{C}\right)\end{array}$} \\
\hline & $\begin{array}{l}\mathrm{CO}_{2} \\
(\%)\end{array}$ & $\begin{array}{l}\mathrm{CH}_{4} \\
\text { (\%) }\end{array}$ & $\mathrm{CO}_{2}(\%)$ & $\mathrm{CH}_{4}(\%)$ \\
\hline $1.1^{*}$ & 11.14 & 88.86 & 10.72 & 88.56 \\
\hline 1.5 & 11.23 & 88.77 & 12.00 & 88.00 \\
\hline 2.5 & 13.95 & 86.05 & 11.88 & 88.12 \\
\hline 3.35 & 14.36 & 85.64 & 12.42 & 87.58 \\
\hline 4.5 & 18.55 & 81.45 & 16.22 & 83.78 \\
\hline 5 & 20.03 & 79.97 & 21.00 & 79.00 \\
\hline
\end{tabular}

$* 0.72 \% \mathrm{H}_{2}$ was detected

Therefore, in the present study, it was considered that hydrogen-consuming microorganisms, such as methanogens, reduced the hydrogen gas due to this conversion. The deterioration of hydrogen gas production with the increasing substrate concentration was in agreement with other reports (Oh et al. 2004; Van Ginkel \& Logan, 2005; Zhang et al. 2007; Şentürk et al. 2010). We thus attributed the reduced production of hydrogen gas to the slower $\beta$-oxidation process at the mesophilic temperature compared to the thermophilic temperature.

The results of this study also showed that the carbon dioxide percentage in the biogas increased with the increasing OLR probably due to the insufficient HRT corresponding to the OLR values under both conditions (Poh \& Chong, 2009). The high carbon dioxide percentages could be a result of the improper balance between the substrate supply, temperature and/or digestion time (Zhao \& Viraraghavan, 2004). In addition, under thermophilic conditions, due to low solubility in water, the concentration of carbon dioxide in the biogas increases (Abdel-Halim, 2005). As the percentage of carbon dioxide in biogas increased, methane production decreased. Therefore, it was concluded that HRT did not directly affect the gas composition. Other researchers have also reported that the produced biogas composition mainly depends on the nature of substrates (Zhao \& Viraraghavan, 2004).

According to the results of the ANOVA analysis, there was a significant difference in the percent of $\mathrm{CO}_{2}$ and $\mathrm{CH}_{4}$ contained in biogas produced at different OLRs $(p<0.05)$. However, there was no significant difference between the mesophilic and thermophilic treatments $(p>0.05)$ in terms of the composition of the produced biogas (Table 5 ). The increase in temperature led to an increase in the amount of biogas but did not have any effect on the biogas composition.

Table 5. The results of the two-way ANOVA analysis

\begin{tabular}{|c|c|c|c|c|c|c|c|c|c|}
\hline \multirow[b]{2}{*}{ Summary } & \multirow[b]{2}{*}{ Count } & \multicolumn{3}{|c|}{$\mathrm{CO}_{2}$} & \multicolumn{3}{|c|}{$\mathrm{CH}_{4}$} & & \\
\hline & & Total & Mean & Variance & Total & Mean & Variance & & \\
\hline Mesophilic & 6 & 89.26 & 14.87667 & 13.68735 & 510.74 & 85.12333 & 13.68735 & & \\
\hline Thermophilic & 6 & 84.24 & 14.04 & 15.1336 & 515.04 & 85.84 & 14.26384 & & \\
\hline OLR (1.1) & 2 & 21.86 & 10.93 & 0.0882 & 177.42 & 88.71 & 0.045 & & \\
\hline $\operatorname{OLR}(1.5)$ & 2 & 23.23 & 11.615 & 0.29645 & 176.77 & 88.385 & 0.29645 & & \\
\hline $\operatorname{OLR}(2.5)$ & 2 & 25.83 & 12.915 & 2.14245 & 174.17 & 87.085 & 2.14245 & & \\
\hline OLR (3.35) & 2 & 26.78 & 13.39 & 1.8818 & 173.22 & 86.61 & 1.8818 & & \\
\hline OLR (4.5) & 2 & 34.77 & 17.385 & 2.71445 & 165.23 & 82.615 & 2.71445 & & \\
\hline OLR6 (5) & 2 & 41.03 & 20.515 & 0.47045 & 158.97 & 79.485 & 0.47045 & & \\
\hline \multicolumn{3}{|c|}{ Source of variation } & SS & df & MS & \multicolumn{2}{|c|}{$\mathbf{F}$} & P-value & F crit \\
\hline \multirow{4}{*}{ Оิ } & \multicolumn{2}{|c|}{ Temperature } & 2.100033 & 1 & 2.100033 & \multicolumn{2}{|c|}{1.911287} & 0.225384 & 6.607891 \\
\hline & \multicolumn{2}{|c|}{ OLRs } & 138.611 & 5 & 27.72219 & \multicolumn{2}{|c|}{25.23059} & 0.001479 & 5.050329 \\
\hline & \multicolumn{2}{|c|}{ Fault } & 5.493767 & 5 & \multicolumn{3}{|l|}{1.098753} & & \\
\hline & \multicolumn{2}{|c|}{ Total } & 146.2048 & 11 & & & & & \\
\hline \multirow{4}{*}{ 売 } & \multicolumn{2}{|c|}{ Temperature } & 1.540833 & 1 & 1.540833 & \multicolumn{2}{|c|}{1.281941} & 0.308897 & 6.607891 \\
\hline & \multicolumn{2}{|c|}{ OLRs } & 133.7462 & 5 & 26.74923 & \multicolumn{2}{|c|}{22.2548} & 0.001988 & 5.050329 \\
\hline & \multicolumn{2}{|c|}{ Fault } & 6.009767 & 5 & \multicolumn{3}{|l|}{1.201953} & & \\
\hline & \multicolumn{2}{|c|}{ Total } & 141.2968 & 11 & & & & & \\
\hline
\end{tabular}




\subsection{Other Parameters}

Another negative effect of the increasing temperature on biological anaerobic treatment has been reported as poor sludge settling, resulting in high-effluent suspended solids, effluent turbidity and biomass washout (Gao et al. 2011). Therefore, in this study, effluent mixed suspended solid (MLSS) concentrations were measured under mesophilic and thermophilic conditions and found to be $141 \mathrm{mg} / \mathrm{L}$ and $152 \mathrm{mg} / \mathrm{L}$, respectively. The small difference between the two temperatures was explained by the presence of a settling tank connected to the reactor. Furthermore, the sludge settleability was better at the optimum mesophilic temperature compared to the thermophilic treatment. As in the effluent phosphate concentration, the effluent ammonia concentrations were similar at both temperatures. Thermophilic conditions are known to cause poor settleability of sludge due to the deterioration of sludge settling properties (Abeynayaka \& Visvanathan, 2011). However, this situation was tolerated by thermophilic anaerobic contact reactors, which are equipped with a settling tank.

\section{Conclusions}

In the present study, the applied maximum OLR was found to be higher under thermophilic conditions compared to the mesophilic treatment with the values being $8 \mathrm{~kg} \mathrm{COD} / \mathrm{m}^{3}$ day and $5 \mathrm{~kg} \mathrm{COD} / \mathrm{m}^{3}$.day, respectively. Accordingly, at lower HRTs, the thermophilic anaerobic reactor operated more effectively. Furthermore, the average methane production $\left(0.42 \mathrm{~m}^{3}\right.$ $\mathrm{CH}_{4} / \mathrm{kg}$ CODremoved) was found to be higher at the thermophilic temperature. Therefore, we conclude that the efficiency of thermophilic anaerobic treatment i325s higher than that of mesophilic anaerobic treatment. For future work, it is recommended that the reasons for the differences in the efficiency of anaerobic contact reactors be investigated by identifying anaerobic microorganisms at mesophilic and thermophilic temperatures.

\section{Acknowledgment}

This study was financially supported by the Technology Research Fund of Gebze Institute (Grant Number: 2008-A-21).

\section{References}

Abdel-Halim W.S. (2005), Anaerobic Municipal Wastewater Treatment. Universität Hannover Inst. f. Siedlungswasserwirtsch, Hannover.

Ahn J.H. and Forster C.F. (2002), The effect of temperature variations on the performance of mesophilic and thermophilic anaerobic filters treating a simulated papermill wastewater, Process Biochem., 37, 589 - 594.

Ahn J.H. and Forster C.F. (2000), Kinetic analyses of the operation of mesophilic and thermophilic anaerobic filters treating a simulated starch wastewater, Process Biochem., 36, 19 - 23.

Ahring B.K., Ibrahim, A.A. and Mladenovska Z. (2001), Effect of temperature increase from $55^{\circ} \mathrm{C}$ to $65^{\circ} \mathrm{C}$ on performance and microbial population dynamics of an anaerobic reactor treating cattle manure, Water Res., 35, 2446 - 2452.
APHA (2005), Standard Methods for the Examination of Water and Wastewater, twenty first ed. American Public Health Association, Washington, DC.

Borja R., González E., Raposo F., Millán F. and Martín A. (2002), Kinetic analysis of the psychrophilic anaerobic digestion of wastewater derived from the production of proteins from extracted sunflower flour, J. Agric. Food Chem., 50, 4628 - 4633.

Buyukkamaci N. and Filibeli A. (2004), Volatile fatty acid formation in an anaerobic hybrid reactor, Process Biochem., 39, 1491 - 1494.

Dinsdale R.M., Hawkes F.R. and Hawkes D.L. (1997), Comparison of mesophilic and thermophilic upflow anaerobic sludge blanket reactors treating instant coffee production wastewater, Water Res., 31, 163 - 169.

El-Mashad H.M., Zeeman G., van Loon W.K.P., Gerard P.A.B. and Lettinga G. (2004), Effect of temperature and temperature fluctuation on thermophilic anaerobic digestion of cattle manure, Bioresource Tech., 95, 191 - 201.

Gao W.J., Leung K.T., Qin W.S. and Liao B.Q. (2011), Effects of temperature and temperature shock on the performance and microbial community structure of a submerged anaerobic membrane bioreactor, Bioresource Tech., 102, $8733-8740$.

Guo W.Q., Ren N.Q., Chen Z.B., Liu B.F., Wang X.J., Xiang W.S. and Ding J. (2008), Simultaneous biohydrogen production and starch wastewater treatment in an acidogenic expanded granular sludge bed reactor by mixed culture for long-term operation, Int. J. Hydrogen Energy, 33, 7397 - 7404.

Hadjivassilis I., Gajdos S., Vavco D. and Nicolauo M. (1997), Treatment of wastewater from the potato chips and snacks manufacturing industry, Water Sci. Technol., 36, 329 - 335.

Harris W.L. and Dague R.R. (1993), Comparative performance of anaerobic filters at mesophilic and thermophilic temperatures, Water Environ. Res., 65, 764 - 771.

Hill D.T., Holmberg R.D. and Bolte J.P. (1985), Operating and performance characteristics of scraped swine manure as a thermophilic anaerobic digestion substrate, Agricultural Wastes, 14, 37-49.

Hung Y.T., Lo H.H., Awad A., Salman, H., 2006. Potato wastewater treatment, In: Waste Treatment in the Food Processing Industry, Wang L.K., Hung Y.-T., Lo H.H. and Yapijakis C. (Eds.), Florida, CRC Press, Taylor and Francis Group.

Iranpour R., Alatriste-Mondragon F., Cox H.H. and Haug R.T. (2005), Effects of transient temperature increases on odor production from thermophilic anaerobic digestion, Water Sci. Technol., 52, 229-235.

Jayaseelan S. and Matsuo T. (1995), Effect of phase separation in anaerobic digestion on different substrates, Water Sci. Tech., 31, 153-162.

Kim M., Ahn Y.-H. and Speece R.E. (2002), Comparative process stability and efficiency of anaerobic digestion; mesophilic vs. thermophilic, Water Res., 36, 4369-4385.

Massé D.I., Masse L. and Croteau F. (2003), The effect of temperature fluctuations on psychrophilic anaerobic sequencing batch reactors treating swine manure, Bioresour. Technol., 89, 57-62.

McInerney M.J. (1988), Anaerobic hydrolysis and fermentation of fats and proteins, In: Biology of Anaerobic Microorganisms, Zehnder A.J.B. (Ed.), New York, Wiley. 
Metcalf and Eddy (2003), Wastewater Engineering: Treatment and Reuse, fourth edition, McGraw Hill Inc., New York, NY.

Meynell P.J. (1976), Methane: planning a digester, London: Prism Press, 55-57.

Ndegwa P.M., Hamilton D.W., Lalman J.A. and Cumba H.J. (2008), Effects of cyclefrequency and temperature on the performance of anaerobic sequencing batch reactors (ASBRs) treating swine waste, Bioresour. Technol., 99, 1972-1980.

Oh Y.-K., Kim S.H., Kim M.-S. and Park S. (2004), Thermophilic biohydrogen production from glucose with trickling biofilter, Biotechnol. Bioeng., 88, 690-698.

Poh P.E. and Chong M.F. (2009), Development of anaerobic digestion methods for palm oil mill effluent (POME) treatment, Bioresource Tech., 100, 1-9.

Şentürk E., Ince M. and Onkal Engin G. (2010), Treatment efficiency and VFA composition of a thermophilic anaerobic contact reactor treating food industry wastewater, J. Hazard. Mater., 176, 843-848.

Switzenbaum M.S. and Jewell W.J. (1980), Anaerobic attached film expanded bed reactor treatment, J. Water Poll. Control. Fed., 52, 1953-1965.

Valentini A., Garuti G., Rozzi A. and Tilche A. (1997), Anaerobic degradation kinetics of particulate organic matter: A new Approach, Water Sci. Technol., 36, 239-246.

Van Ginkel S.W. and Logan B. (2005), Increased biological hydrogen production with reduced organic loading, Water Res., 39, 2819-2826.

Water Pollution Control Federation, 1987. Anaerobic Sludge Digestion, Manual Practice No. 16 second ed. Alexandria: Techna Type, Inc.

Yilmaz, T., Yuceer, A., Basibuyuk, M., (2008). A comparison of the performance of mesophilic and thermophilic anaerobic filters treating papermill wastewater. Bioresource Technol., 99, 156-163.

Yu H.Q., Fang H.H.P. and Gu G.-W. (2002), Comparative performance of mesophilic and thermophilic acidogenic upflow reactors, Process Biochem., 38, 447-454.

Zhang Z.P., Tay J.H., Show K.Y., Yan R., Liang D.T. and Lee D.J. (2007), Biohydrogen production in a granular activated carbon anaerobic fluidized bed reactor, Int. J. Hydrogen Energy, 32, 185-191.

Zhao H.W. and Viraraghavan T. (2004), Analysis of the performance of an anaerobic digestion system at the Regina wastewater treatment plant, Bioresource Tech., 95, 301-307. 